\title{
Hubungan Awitan Pengobatan Hipotiroid Kongenital dengan Gangguan Perkembangan Anak di Rumah Sakit Umum Pusat Dr. Hasan Sadikin
}

Adhitya Agung Pratama, Alex Chairulfatah, Novina, Faisal, Eddy Fadlyana

Departemen Ilmu Kesehatan Anak Fakultas Kedokteran Universitas Padjadjaran/ Rumah Sakit Hasan Sadikin Bandung

Latar belakang. Hipotiroid kongenital $(\mathrm{HK})$ adalah kondisi kekurangan hormon tiroid, tiroksin, dan tri-iodotironina sejak lahir yang dapat menyebabkan gangguan organogenesis sistem saraf pusat serta metabolisme tubuh. Penderita HK yang tidak diterapi dapat berlanjut menjadi individu dengan gangguan perkembangan. Data di Indonesia dari Ikatan Dokter Anak Indonesia (IDAI) sejak tahun 2000-2013, angka kejadian HK pada bayi baru lahir sebanyak 1:2736.

Tujuan. Mengetahui hubungan awitan pengobatan dengan gangguan perkembangan pada anak dengan HK.

Metode. Penelitian observasional analitik dengan pendekatan potong lintang yang dilakukan periode bulan Agustus-November 2018. Subjek HK datang kontrol ke klinik rawat jalan endokrin dan tumbuh kembang RS. Hasan Sadikin, berusia $<36$ bulan dan mendapat terapi levotiroksin, dilakukan penilaian perkembangan dengan pemeriksaan Denver dan CAT/ CLAMS (cognitive adaptive test/ clinical linguistic auditory milestone scale). Analisis data menggunakan uji chi-kuadrat dan Mann Whitney $(\mathrm{p}<0,05)$.

Hasil. Terdapat 92 kasus HK, 12 dieksklusi, subjek terdiri dari 38 laki-laki dan 42 perempuan dengan rerata usia diagnosis 3,0 bulan (0,5-22,0 bulan). Didapatkan adanya hubungan usia saat diagnosis dan awitan pengobatan dengan gangguan perkembangan $(\mathrm{p}<0,001)$. Usia saat diagnosis dan awitan pengobatan $>3$ bulan lebih banyak mengalami gangguan perkembangannya.

Kesimpulan. Pasien HK yang terlambat didiagnosis dan diberikan terapi akan mengalami gangguan perkembangan yang lebih banyak. Sari Pediatri 2019;21(1):16-23

Kata kunci: CAT/CLAMS, Denver, gangguan perkembangan, hipotiroid kongenital

\section{Relation between Onset of Congenital Hypothyroidism Treatment with Child Developmental Disorders at Dr. Hasan Sadikin General Hospital}

Adhitya Agung Pratama, Alex Chairulfatah, Novina, Faisal, Eddy Fadlyana

Background. Congenital Hypothyroidism $(\mathrm{CH})$ is an inadequacy condition of thyroid hormones, thyroxine, and triiodothyronine which cause metabolic and central nervous system organogenesis disorder. Untreated CH children are at risk to become individuals with developmental disorder. Data from the Indonesian Pediatric Society, from 2000-2013 the incidence of CH in newborns was 1: 2,736. Objective. To identify the relationship between the onset of treatment and developmental in children with $\mathrm{CH}$.

Methods. This was analytical observational study with cross-sectional approach conducted between August-November 2018. The $\mathrm{CH}$ subjects came to Endocrinology and Growth-Developmental clinic of Hasan Sadikin Hospital were 36 months old and given levothyroxine. The subjects were evaluated with Denver and CAT/CLAMS (Cognitive Adaptive Test/ Clinical Linguistic Auditory Milestone Scale), analyzed using chi-square and Mann Whitney tests $(\mathrm{p}<0.05)$.

Result. Ninety two cases of $\mathrm{CH}$ were found, 12 excluded, subjects consisted of 38 boys and 42 girls (mean=3 months). There was relation between the onset of diagnosis and treatment with developmental disorder $(\mathrm{p}<0.001)$. Onset of diagnosis and initial treatment $>3$ months were found to have developmental disorders more.

Conclusions. Congenital hypothyroid patients who were late in diagnosis and therapy had more developmental disorders. Sari Pediatri 2019;21(1):16-23

Keywords: CAT/CLAMS, congenital hypothyroidism, Denver, development disorder 
S etiap anak diharapkan dapat tumbuh dan berkembang optimal sejak saat pembuahan hingga dewasa sesuai dengan periode usianya. Proses tumbuh kembang anak yang dimulai saat pembuahan hingga mencapai masa remaja dipengaruhi oleh berbagai faktor internal dan eksternal. Salah satu faktor internal adalah fungsi hormon tiroid yang adekuat. Penurunan kadar hormon tiroid saat lahir dapat menyebabkan hipotiroid kongenital. Hipotiroid kongenital adalah kondisi kekurangan hormon tiroid, tiroksin dan tri-iodotironina sejak lahir sehingga menyebabkan gangguan proses metabolisme dan organogenesis sistem saraf pusat. Angka kejadian HK bervariasi di setiap negara dengan kisaran 1:1.660 hingga 1:2.828 kelahiran hidup, bahkan di daerah endemik bisa mencapai 1:900 kelahiran hidup. Di negara Asia, angka kejadian di Singapura 1:3000-3500, Malaysia 1:3026, Filipina 1:3460, Hongkong 1:2404 kelahiran hidup. Berdasarkan data yang dikumpulkan oleh Unit Koordinasi Kerja Endokrinologi Anak Ikatan Dokter Anak Indonesia (IDAI) sejak tahun 2000-2013, terdapat kasus gangguan tiroid pada bayi baru lahir sebanyak 1:2736 kelahiran hidup. ${ }^{1-7}$

Hormon tiroid berperan penting dalam pembentukan dan pematangan sistem saraf pusat Bayi dengan $\mathrm{HK}$ yang tidak diobati dapat berlanjut menjadi individu dengan disabilitas intelektual dan disertai defisit motorik, seperti gangguan fungsi motorik kasar dan halus, serta koordinasi keseimbangan. Penelitian lain juga menyimpulkan bahwa masalah keterampilan motorik halus dapat disebabkan oleh penurunan fungsi visual-motor dan visual-spasial, serta masalah pada memori dan perhatian. Alat skrining digunakan untuk memantau anak dengan kecurigaan gangguan neuropsikomotor yang disebabkan oleh HK. Alat skrining berupa prosedur cepat dan dirancang untuk stimulasi atau intervensi sedini mungkin bagi anak yang diidentifikasi perlu dirujuk untuk evaluasi lebih lanjut . Amerika Serikat dan Kanada untuk pertama kalinya pada tahun 1974 di Quebec dan Pittsburgh melakukan serangkaian studi percontohan untuk menguji kelayakan penggunaan uji kertas saring kepada bayi baru lahir untuk skrining HK. Indonesia juga sudah memulai skrining HK pada bayi baru lahir. Indonesia dengan bantuan dari International Atomic Energy Agency (IAEA) telah melakukan penapisan HK di RS. dr. Hasan Sadikin (RSHS) dan RS Cipto Mangunkusumo. Selama tahun 2000-2005 telah dilakukan uji saring HK pada 55.647 bayi di
RSHS dan RSCM. Telaah rekam medis di RSCM dan RSHS menunjukkan bahwa lebih dari 70\% kasus HK didiagnosis setelah umur 1 tahun sehingga telah mengalami keterbelakangan mental yang permanen. $^{2-4,7-17}$

Bayi yang mengalami HK memerlukan terapi subtitusi dengan pemberian levotiroksin dalam jangka waktu tertentu dan berbagai stimulasi perkembangan agar tercapai tumbuh kembang optimal. Skrining perkembangan anak sebaiknya dilakukan dengan skala penilaian yang memenuhi validitas, realibilitas, sensitivitas, spesifisitas, akseptabilitas, dan kesesuaian dengan kondisi setempat. Salah satu alat skrining yang banyak digunakan adalah Denver Developmental Screening Test (DDST) yang dapat digunakan pada anak sejak lahir hingga 6 tahun (sensitivitas $83 \%$ spesifisitas 43\%). Penilaian fungsi kognitif dilakukan dengan The Cognitive Adaptive Test/Clinical Linguistic and Auditory Milestone Scale (CAT/CLAMS) yang bisa digunakan pada anak usia 1 bulan hingga 36 bulan (sensitivitas 67\% spesifisitas 95\%). 4, 9, 11, 15, 18, 19 Pada penelitian ini, kedua pemeriksaan tetap dilakukan pada semua pasien karena dilakukan di rumah sakit pendidikan. Tujuan dari penelitian ini adalah untuk menilai hubungan awitan pengobatan dengan gangguan perkembangan anak dengan hipotiroid kongenital yang kontrol ke klinik rawat jalan endokrin anak Rumah Sakit Umum Pusat dr. Hasan Sadikin.

\section{Metode}

Penelitian ini merupakan penelitian observasional analitik dengan pendekatan potong lintang. Penelitian dilakukan pada penyandang $\mathrm{HK}$ anak yang kontrol pengobatan levotiroksin di klinik endokrin anak RSHS periode bulan Agustus hingga November 2018. Penentuan jumlah sampel dengan uji beda kategorik tidak berpasangan yang diambil secara konsekutif sampai subjek minimum terpenuhi. Kriteria inklusi adalah pasien yang didiagnosis HK dan berobat teratur di klinik rawat jalan endokrin anak RSHS dan telah mendapatkan persetujuan tertulis dari orang tua dengan menandatangani lembar persetujuan (informed consent). Kriteria eksklusi adalah pasien yang memiliki faktor yang dapat mengganggu status perkembangan anak (penyakit jantung bawaan berat, palsi serebri dan sindrom Down). Diagnosis HK ditegakkan berdasarkan pemeriksaan TSH, fT4 serum 
dan skintigrafi kelenjar tiroid. Subjek yang datang dilakukan anamnesis, pemeriksaan antropometri dan penilaian perkembangan dengan menggunakan metode DDST dan CAT/CLAMS. Penentuan status nutrisi menggunakan kriteria WHO Child Growth Standards. Tujuan penelitian untuk mengetahui hubungan awitan pengobatan dengan gangguan perkembangan anak HK yang didiagnosis di RSHS. Penelitian ini telah mendapat persetujuan Komite Etik Penelitian Kesehatan RS Hasan Sadikin.

Data dianalisis dengan uji bivariat menggunakan chi-square untuk data kategorik dan uji Mann Whitney untuk data numerik dengan sebaran data tidak berdistribusi normal. Tingkat kemaknaan dalam penelitian ini dinyatakan bila $\mathrm{p}<0,05$. Analisis dilakukan dengan program perangkat lunak SPSS 25.

\section{Hasil}

Dalam kurun waktu penelitian didapatkan 92 kasus HK, 12 pasien tidak diikutsertakan dalam penelitian karena mengalami komorbid, di antaranya sindrom Down, penyakit jantung bawaan berat dan palsi serebri. Subjek penelitian terdiri dari 38 laki-laki dan 42 perempuan. Subjek memiliki rerata usia 15 bulan dengan sebaran usia $\leq 12$ bulan 38 anak dan $\geq 12$ bulan sebanyak 42 anak. Usia saat diagnosis HK pada pasien rerata pada usia 3 bulan. Karakteristik subjek dari penelitian ini tertera pada Tabel 1 .

Dari Tabel 2 didapat anak usia $>12$ bulan lebih banyak mengalami gangguan perkembangan ( $p$

Tabel 1. Karakteristik pasien hipotiroid kongenital

\begin{tabular}{lcc}
\hline Karakteristik & Jumlah & $\%$ \\
\hline Jenis kelamin & & \\
$\quad$ Laki-laki & 38 & 47,5 \\
$\quad$ Perempuan & 42 & 52,5 \\
Status gizi & & \\
$\quad$ Normal & 49 & 61,2 \\
$\quad$ Malnutrisi sedang & 19 & 23,8 \\
$\quad$ Malnutrisi berat & 12 & 15,0 \\
Etiologi & & \\
$\quad$ Kelenjar tiroid ektopik & 1 & 1,25 \\
Agenesis tiroid & 22 & 27,5 \\
$\quad$ Hipoplasia tiroid & 11 & 13,7 \\
$\quad$ Dishormogenesis & 18 & 22.5 \\
$\quad$ Tidak diketahui & 28 & 35,0 \\
\hline
\end{tabular}

$<0,001)$. Tidak terdapat hubungan antara status gizi, tingkat pendidikan orangtua atau etiologi $\mathrm{HK}$ dengan gangguan perkembangan $(\mathrm{p}=0,885, \mathrm{p}=0,178, \mathrm{p}=0,601$, $\mathrm{p}=0,682)$

Tabel 3 menunjukkan bahwa tidak terdapat hubungan antara berat badan lahir dengan tingkat perkembangan anak $(p>0,05)$. Pasien dengan usia saat diagnosis dan pengobatan $>3$ bulan lebih banyak mengalami gangguan perkembangan menurut Denver $(\mathrm{p}<0,001$ dan $\mathrm{p}<0,001)$

Tabel 4 menunjukkan bahwa gangguan perkembangan dengan pemeriksaan CAT/ CLAMS lebih sering didapatkan pada anak usia $>12$ bulan $(\mathrm{p}=0,001)$. Tidak ada hubungan bermakna gangguan perkembangan menurut pemeriksaan CAT/CLAMS dengan status gizi, pendidikan orangtua dan etiologi HK ( $p=0,340, p=0,594, p=0,873$, dan $p=0,114)$

Tabel 5 menunjukkan bahwa usia saat diagnosis dan pengobatan $>3$ bulan secara bermakna lebih banyak mengalami gangguan perkembangan menurut pemeriksaan CAT/ CLAMS (masing-masing $\mathrm{p}<0,001$ dan $\mathrm{p}<0,001)$. Usia saat diagnosis dan awal pengobatan anak $>3$ bulan lebih banyak mengalami suspect dan disabilitas intelektual dengan masing-masing median 8 bulan. Tidak terdapat perbedaan bermakna antar gangguan perkembangan menurut pemeriksaan CAT/ CLAMS dengan berat badan lahir.

\section{Pembahasan}

Hipotiroid kongenital adalah kelainan endokrin paling umum dengan insiden sekitar 1:2000-4000 bayi baru lahir. Hipotiroid kongenital menjadi penyebab utama keterbelakangan mental dan delayed neuro psikomotor development (NPMD). Namun, penyakit ini dapat dicegah dengan melakukan skrining rutin pada bayi baru lahir dan pemberian terapi sedini mungkin. Pasien HK dapat diterapi dengan pemberian levotiroksin agar dapat memenuhi kebutuhan metabolisme tubuh dan stimulasi atau fisioterapi yang tepat. ${ }^{4,8,10,20}$

Rerata usia saat diagnosis $\mathrm{HK}$ dari populasi subjek $>3$ bulan, sebagian besar pasien berusia $>12$ bulan. Status gizi dan tingkat pendidikan orang tua tidak memengaruhi gangguan perkembangan pada pasien. Hasil penelitian ini menemukan gangguan perkembangan dengan Denver sebanyak 34 anak dan 46 anak dengan CAT/CLAMS (8 suspect, 32 disabilitas intelektual dan 6 gangguan komunikasi). 
Pada tahun 2017, Scharf ${ }^{22}$ melakukan studi yang menyimpulkan bahwa bayi berat badan lahir rendah memiliki nilai Bayley lebih rendah dibanding yang lahir dengan berat normal. Hal tersebut disebabkan karena penambahan berat pada bayi berbanding lurus dengan volume otak. Nakamizo ${ }^{21}$ kemudian melakukan penelitian lanjutan pada bayi $\mathrm{HK}$ dan menyimpulkan bahwa terdapat tiga faktor yang memengaruhi buruknya luaran perkembangan intelektual pada bayi HK, yaitu berat badan lahir rendah, komorbiditas, dan tingginya kadar TSH pada saat diagnosis. Pada penelitian ini berat badan lahir terbukti tidak berpengaruh terhadap adanya gangguan pada perkembangan. ${ }^{21,22}$

Pemberian terapi pada HK berupa obat pengganti hormon bernama natrium levotiroksin yang diberikan sesuai usia. Tujuan pemberian untuk mencapai keadaan eutiroid (kadarT4 dan TSH normal). Pemberian obat sebaiknya sedini mungkin dan disertai pemantauan tumbuh kembang, usia tulang, pubertas dan IQ bila memungkinkan. Bongers ${ }^{23}$ mengungkapkan pemberian terapi optimal hingga mencapai keadaan eutiroid dan kadar FT4 yang dipertahankan sampai pada batas atas selama 1 tahun pertama kehidupan dapat mencapai perkembangan psikomotor normal saat usia 10-30 bulan. Pada penelitian ini memiliki hasil yang berbeda, sampai dengan usia 3 tahun sebagian besar pasien mengalami gangguan perkembangan ditinjau dari hasil penilaian Denver dan CAT/CLAMS karena subjek memiliki keadekuatan terapi yang berbeda-beda, baik berupa usia awitan pengobatan maupun stimulasi atau fisioterapi.

Pada anak HK, defisiensi hormon tiroid terjadi sejak masa prenatal, hormon tiroid sangat penting untuk perkembangan otak, pasien HK berisiko tinggi mengalami kerusakan otak berupa defisiensi kognitif dan motorik seumur hidupnya. Diagnosis dini dan

Tabel 2. Hubungan karakteristik subjek dengan gangguan perkembangan menggunakan DDST

\begin{tabular}{|c|c|c|c|c|}
\hline \multirow[b]{2}{*}{ Variabel } & \multirow{2}{*}{$\begin{array}{c}\text { Semua pasien } \\
\mathrm{n}=80\end{array}$} & \multicolumn{2}{|c|}{ Perkembangan (Denver) } & \multirow[b]{2}{*}{$\mathrm{p}$} \\
\hline & & $\begin{array}{c}\text { Suspect } \\
\mathrm{n}=46\end{array}$ & $\begin{array}{c}\text { Normal } \\
\mathrm{n}=34\end{array}$ & \\
\hline \multicolumn{5}{|l|}{ Kategori usia (bulan) } \\
\hline$\leq 12$ & $38(47,5)$ & $14(30,4)$ & $24(70,6)$ & $0,001^{\mathrm{a} *}$ \\
\hline$>12$ & $42(52,5)$ & $32(69,6)$ & $10(29,4)$ & \\
\hline \multicolumn{5}{|l|}{ Status gizi } \\
\hline Normal & $49(61,3)$ & $29(63,0)$ & $20(58,8)$ & $0,885^{\mathrm{a}}$ \\
\hline Malnutrisi sedang & $19(23,8)$ & $10(21,7)$ & $9(26,5)$ & \\
\hline Malnutrisi berat & $12(15,0)$ & $7(15,3)$ & $5(14,7)$ & \\
\hline \multicolumn{5}{|l|}{ Pendidikan orang tua } \\
\hline \multicolumn{5}{|l|}{ Ayah, n(\%) } \\
\hline $\mathrm{SD}$ & $11(13,8)$ & $6(13,0)$ & $5(14,7)$ & $0,178^{\mathrm{a}}$ \\
\hline SMP & $29(36,3)$ & $19(41,3)$ & $10(29,4)$ & \\
\hline SMA & $34(42,5)$ & $20(43,5)$ & $14(41,2)$ & \\
\hline Perguruan tinggi & $6(7,5)$ & $1(2,2)$ & $5(14,7)$ & \\
\hline \multicolumn{5}{|l|}{ Ibu, $\mathrm{n}(\%)$} \\
\hline $\mathrm{SD}$ & $12(15,0)$ & $6(13,0)$ & $6(17,6)$ & $0,601^{a}$ \\
\hline SMP & $37(46,3)$ & $24(52,2)$ & $13(38,2)$ & \\
\hline SMA & $26(32,5)$ & $14(30,4)$ & $12(35,3)$ & \\
\hline Perguruan tinggi & $5(6,3)$ & $2(4,3)$ & $3(8,8)$ & \\
\hline Etiologi & $\mathrm{n}=52$ & $\mathrm{n}=34$ & $\mathrm{n}=18$ & \\
\hline Kelenjar tiroid ektopik & $1(1,9)$ & $1(2,9)$ & $0(0,0)$ & $0,682^{\mathrm{a}}$ \\
\hline Agenesis tiroid & $22(42,3)$ & $14(41,2)$ & $8(44,4)$ & \\
\hline Hipoplasia tiroid & $11(21,2)$ & $6(17,6)$ & $5(27,8)$ & \\
\hline Dishormogenesis & $18(34,6)$ & $13(38,2)$ & $5(27,8)$ & \\
\hline
\end{tabular}

Keterangan: $\mathrm{n}=$ frekuensi, $\%=$ persentase, uji berdasarkan achi square, *signifikan $\mathrm{p}<0,05$ 
Tabel 3. Hubungan awitan pengobatan dengan tingkat perkembangan anak menggunakan DDST

\begin{tabular}{|c|c|c|c|c|}
\hline \multirow[b]{2}{*}{ Variabel } & \multirow{2}{*}{$\begin{array}{c}\text { Semua Pasien } \\
\mathrm{n}=80\end{array}$} & \multicolumn{2}{|c|}{ Tingkat perkembangan (Denver) } & \multirow[b]{2}{*}{$\mathrm{p}$} \\
\hline & & $\begin{array}{c}\text { Suspect } \\
\mathrm{n}=46\end{array}$ & $\begin{array}{c}\text { Normal } \\
\mathrm{n}=34\end{array}$ & \\
\hline \multicolumn{5}{|c|}{ Berat badan lahir (kg) } \\
\hline$\leq 2,5$ & $30(37,5)$ & $16(34,8)$ & $14(41,2)$ & $0,559^{\mathrm{a}}$ \\
\hline$>2,5$ & $50(62,5)$ & $30(65,2)$ & $20(58,8)$ & \\
\hline \multicolumn{5}{|c|}{ Usia saat diagnosis, bulan, $\mathrm{n}(\%)$} \\
\hline$\leq 3$ & $42(52,5)$ & $8(17,4)$ & $34(100)$ & $<0,001^{\text {a* }}$ \\
\hline$>3$ & $38(47,5)$ & $38(82,6)$ & $0(0,0)$ & \\
\hline \multicolumn{5}{|c|}{ Awitan pengobatan, bulan, $\mathrm{n}(\%)$} \\
\hline$\leq 3$ & $40(50,0)$ & $6(13,0)$ & $34(100)$ & $<0,001^{\text {a* }}$ \\
\hline$>3$ & $40(50,0)$ & $40(87,0)$ & $0(0,0)$ & \\
\hline
\end{tabular}

Keterangan: $\mathrm{n}=$ frekuensi, $\%=$ persentase, uji berdasarkan ${ }^{a}$ chi square, ${ }^{\mathrm{b}}$ Mann Whitney, ${ }^{*}$ signifikan $\mathrm{p}<0,05$

Tabel 4. Hubungan karakteristik subjek dengan tingkat perkembangan menggunakan CAT/CLAMS

\begin{tabular}{|c|c|c|c|c|c|c|}
\hline \multirow[b]{3}{*}{ Variabel } & \multirow{3}{*}{$\begin{array}{c}\text { Semua pasien } \\
\mathrm{n}=80\end{array}$} & \multicolumn{4}{|c|}{ Tingkat perkembangan (CAT/CLAMS) } & \multirow[b]{3}{*}{$\mathrm{p}$} \\
\hline & & \multirow[b]{2}{*}{$\begin{array}{c}\text { Normal } \\
\mathrm{n}=34\end{array}$} & \multicolumn{3}{|c|}{ Tidak normal } & \\
\hline & & & $\begin{array}{c}\text { Suspect } \\
\mathrm{n}=8\end{array}$ & $\begin{array}{c}\text { Disabilitas } \\
\text { intelektual } \\
\mathrm{n}=32\end{array}$ & $\begin{array}{c}\text { Gangguan } \\
\text { Komunikasi } \\
\mathrm{n}=6\end{array}$ & \\
\hline \multicolumn{7}{|l|}{ Kategori usia (bulan) } \\
\hline$\leq 12$ & $38(47,5)$ & $24(70,6)$ & $5(62,5)$ & $6(18,8)$ & $3(50,0)$ & $0,001^{\text {a* }}$ \\
\hline$>12$ & $42(52,5)$ & $10(29,4)$ & $3(37,5)$ & $26(81,2)$ & $3(50,0)$ & \\
\hline \multicolumn{7}{|l|}{ Status gizi } \\
\hline Normal & $49(61,3)$ & $20(58,8)$ & $7(87,5)$ & $19(59,4)$ & $3(50,0)$ & $0,340^{\mathrm{a}}$ \\
\hline Malnutrisi sedang & $19(23,8)$ & $9(26,5)$ & $1(12,5)$ & $6(18,8)$ & $3(50,0)$ & \\
\hline Malnutrisi berat & $12(15,0)$ & $5(14,7)$ & $0(0,0)$ & $7(21,9)$ & $0(0,0)$ & \\
\hline \multicolumn{7}{|l|}{ Pendidikan orang tua } \\
\hline \multicolumn{7}{|l|}{ Ayah, n (\%) } \\
\hline SD & $11(13,8)$ & $5(14,7)$ & $2(25,0)$ & $3(9,4)$ & $1(16,7)$ & $0,594^{a}$ \\
\hline SMP & $29(36,3)$ & $10(29,4)$ & $2(25,0)$ & $15(46,9)$ & $2(33,3)$ & \\
\hline SMA & $34(42,5)$ & $14(41,2)$ & $4(50,0)$ & $13(40,6)$ & $3(50,0)$ & \\
\hline Perguruan tinggi & $6(7,5)$ & $5(14,7)$ & $0(0,0)$ & $1(3,1)$ & $0(0,0)$ & \\
\hline \multicolumn{7}{|l|}{ Ibu, n (\%) } \\
\hline SD & $12(15,0)$ & $6(17,6)$ & $1(12,5)$ & $4(12,5)$ & $1(16,7)$ & $0,873^{\mathrm{a}}$ \\
\hline SMP & $37(46,3)$ & $13(38,2)$ & $3(37,5)$ & $17(53,1)$ & $4(66,7)$ & \\
\hline SMA & $26(32,5)$ & $12(35,3)$ & $4(50,0)$ & $9(28,1)$ & $1(16,7)$ & \\
\hline Perguruan tinggi & $5(6,3)$ & $3(8,8)$ & $0(0,0)$ & $2(6,3)$ & $0(0,0)$ & \\
\hline Etiologi & $\mathrm{n}=52$ & $\mathrm{n}=18$ & $\mathrm{n}=4$ & $\mathrm{n}=26$ & $\mathrm{n}=4$ & \\
\hline Tiroid ektopik & $1(1,9)$ & $0(0,0)$ & $1(25,0)$ & $0(0,0)$ & $0(0,0)$ & $0,114^{a}$ \\
\hline Agenesis tiroid & $22(42,3)$ & $8(44,4)$ & $1(25,0)$ & $12(46,1)$ & $1(25,0)$ & \\
\hline Hipoplasia tiroid & $11(21,2)$ & $5(27,8)$ & $1(25,0)$ & $4(15,4)$ & $1(25,0)$ & \\
\hline Dishormogenesis & $18(34,6)$ & $5(27,8)$ & $1(25,0)$ & $10(38,5)$ & $2(50,0)$ & \\
\hline
\end{tabular}

Keterangan: $\mathrm{n}=$ frekuensi, \%=persentase, uji berdasarkan ${ }^{a}$ Chi square, ${ }^{*}$ signifikan $\mathrm{p}<0,05$ 
Adhitya Agung Pratama dkk: Hubungan awitan pengobatan HK dengan gangguan perkembangan

Tabel 5. Hubungan awitan pengobatan dengan gangguan perkembangan anak menggunakan CAT/CLAMS

\begin{tabular}{|c|c|c|c|c|c|c|}
\hline \multirow[b]{2}{*}{ Variabel } & \multirow{2}{*}{$\begin{array}{c}\text { Semua } \\
\text { pasien } \\
\mathrm{n}=80\end{array}$} & \multirow{2}{*}{$\begin{array}{c}\text { Normal } \\
\mathrm{n}=34\end{array}$} & \multicolumn{3}{|c|}{$\begin{array}{l}\text { Tingkat perkembangan } \\
\text { (CAT/CLAMS) }\end{array}$} & \multirow[t]{2}{*}{$\mathrm{p}$} \\
\hline & & & $\begin{array}{c}\text { Suspect } \\
\mathrm{n}=8\end{array}$ & $\begin{array}{c}\text { Disabilitas } \\
\text { intelektual } \\
n=32\end{array}$ & $\begin{array}{c}\text { Gangguan } \\
\text { komunikasi } \\
\mathrm{n}=6\end{array}$ & \\
\hline \multicolumn{7}{|c|}{ Berat badan lahir (kg) } \\
\hline$\leq 2,5$ & $30(37,5)$ & $14(41,2)$ & $4(50,0)$ & $10(31,3)$ & $2(33,3)$ & $0,727^{\mathrm{a}}$ \\
\hline$>2,5$ & $50(62,5)$ & $20(58,8)$ & $4(50,0)$ & $22(68,8)$ & $4(66,7)$ & \\
\hline \multicolumn{7}{|c|}{ Usia saat diagnosis, bulan, $\mathrm{n}(\%)$} \\
\hline$\leq 3$ & $42(52,5)$ & $34(100)$ & $3(37,5)$ & $1(3,1)$ & $4(66,7)$ & $<0,001^{a *}$ \\
\hline$>3$ & $38(47,5)$ & $0(0,0)$ & $5(62,5)$ & $31(96,9)$ & $2(33,3)$ & \\
\hline \multicolumn{7}{|c|}{ Awitan pengobatan, bulan, n (\%) } \\
\hline$\leq 3$ & $40(50,0)$ & $34(100)$ & $2(25,0)$ & $0(0,0)$ & $4(66,7)$ & $<0,001^{a *}$ \\
\hline$>3$ & $40(50,0)$ & $0(0,0)$ & $6(75,0)$ & $32(100,0)$ & $2(33,3)$ & \\
\hline
\end{tabular}

Keterangan: $\mathrm{n}=$ frekuensi, $\%=$ persentase, uji berdasarkan ${ }^{\mathrm{a}}$ chi square, ${ }^{*}$ signifikan $\mathrm{p}<0,05$

suplementasi awal levotiroksin setelah lahir, dapat dilakukan berkat adanya program skrining neonatal. Pada penelitian ini, kebanyakan pasien dilakukan terapi tidak lama setelah dosis HK ditegakkan. Rerata usia terapi 3,5 bulan, tetapi sebagian besar pasien mengalami gangguan perkembangan. Penelitian Wirawan $\mathrm{dkk}^{24}$ menyebutkan bahwa pemberian terapi sejak dini akan memberikan luaran pertumbuhan dan perkembangan intelektual yang lebih baik. Wirawan dkk menyebutkan beberapa kondisi yang mungkin berperan terhadap luaran meliputi derajat keparahan penyakit, komorbid, dan keadekuatan terapi levotiroksin yang diberikan seperti dosis, ketaatan minum obat, dan ketaatan kontrol rutin. 4,9,11,24

Pada pasien HK dapat juga disertai atau didiagnosis banding dengan penyakit sindrom Down yang akan menghasilkan luaran perkembangan yang terlambat. ${ }^{25}$ Pada penelitian ini, dari 92 subjek HK, 12 pasien dieksklusi karena disertai penyakit jantung bawaan berat, sindrom Down, dan palsi serebri. Subjek yang dimasukan ke dalam penelitian sebagian besar juga menyerupai tampilan sindrom Down, tetapi tidak semuanya dilakukan pemeriksaan kromosom. Hal ini mungkin dapat menjelaskan masih banyak subjek yang mengalami gangguan perkembangan walapun sudah mendapatkan terapi yang adekuat. ${ }^{25}$

Penelitian Pop dkk memeriksa sekitar 220 ibu dengan konsentrasi tiroksin serum yang rendah pada saat kehamilan 12 minggu dan kemudian melahirkan bayi yang pada usia 10 bulan dilakukan penilaian dengan indeks skala perkembangan psikomotor Bayley untuk bayi dan menunjukkan skor di bawah persentil sepuluh dibandingkan bayi normal. ${ }^{26}$ Haddow $\mathrm{dkk}^{27}$ melakukan sebuah penelitan pada ibu untuk melihat perkembangan neuropsikologis anak HK dengan menilai kecerdasan, perhatian, bahasa, kemampuan membaca, kinerja di sekolah, dan kinerja visual motor. Tes intelegensia diukur menggunakan Skala Kecerdasan Wechsler untuk anak Skala Wechsler merupakan tes kecerdasan yang paling banyak digunakan. Penelitian ini menunjukkan hasil adanya gangguan perkembangan saraf yang lebih besar pada anak yang tidak diobati. Skor anak HK dari 15 tes lebih buruk daripada anak normal. Skor IQ rata-rata 7 poin lebih rendah, dan sekitar 19\% anak dengan hipotiroid memiliki nilai IQ 85 atau lebih rendah dibandingkan anak normal yang hanya $5 \%$. Pada penelitian ini, pemeriksaan yang digunakan adalah CAT/CLAMS dengan hasil akhir, yaitu 32 subjek disabilitas intelektual, 8 suspect, dan 6 subjek mengalami gangguan komunikasi. ${ }^{27,28}$

Defisit hormon hipotiroid dapat menyebabkan kerusakan pada area otak yang berbeda, antara lain, korteks parietal posterior yang bertanggung jawab atas kesadaran spasial; lobus temporal inferior bertanggung jawab untuk pengidentifikasian benda, nucleus kaudatus yang berhubungan dengan perhatian, serta hippocampus yang berhubungan dengan memori. Ada juga laporan yang menyebutkan mengenai defisit/ gangguan pendengaran. Defisit hormon tiroid juga dapat menyebabkan kelemahan di bidang persepsi, kognitif, bahasa, sosial, dan kemandirian, serta gangguan dalam bahasa. Pada penelitian ini dengan menggunakan CAT/CLAMS dapat disimpulan subjek 
paling banyak mengalami disabilitas intelektual, diikuti hasil suspect dan gangguan komunikasi. Sebagian besar subjek diakui oleh orang tua sudah menjalani pengobatan rutin. Namun, masih banyak pasien yang mendapat hasil adanya gangguan perkembangan. Hasil ini masih mungkin diakibatkan beberapa faktor, seperti derajat keparahan, awitan pengobatan, komorbid, dan keadekuatan terapi levotiroksin. ${ }^{4,9,15}$

Hipotiroid kongenital secara nyata merupakan penyakit yang dapat menurunkan kualitas kehidupan setiap individu yang akan berdampak pada kemajuan suatu bangsa. Program skrining HK merupakan salah satu cara yang terbukti efektif dalam menurunkan morbiditas penyakit ini. Sampai saat ini, program skrining HK pemerintah belum berjalan optimal. Hal tersebut dikarenakan adanya keterbatasan proses skrining/pengambilan sampel, pelaporan hasil hingga tindak lanjut stimulasi/ intervensi terhadap pasien yang positif. Pada penelitian ini hampir semua pasien yang datang bukan hasil dari program skrining HK sehingga dikhawatirkan jumlah pasien HK yang sebenarnya masih mungkin lebih besar.

Beberapa keterbatasan penelitian ini meliputi ketidaklengkapan hasil pemeriksaan kromosom pada subjek sehingga dapat menjadi bias hasil penelitian, data yang kurang mengenai pemberian intervensi fisioterapi juga mengakibatkan hasil penelitian yang berbeda karena pada dasarnya stimulasi/ intervensi fisioterapi merupakan faktor yang dapat memengaruhi luaran perkembangan pada pasien $\mathrm{HK}$.

\section{Kesimpulan}

Gangguan perkembangan pada anak HK dapat dicegah apabila dilakukan deteksi dini, pemberian obat levotiroksin teratur dan stimulasi/ intervensi fisioterapi yang baik. Dari hasil penelitian ini, usia saat diagnosis dan terapi sedini mungkin menjadi faktor penentu perkembangan normal, pasien yang didiagnosis dan diberikan terapi $>3$ bulan lebih banyak mengalami gangguan perkembangan.

\section{Daftar pustaka}

1. Depkes. Situasi dan Analisis Penyakit Tiroid. In: Indonesia DKR, penyunting. Jakarta: Depkes; 2015.

2. Bona G, Bellone S, Prodam F, Monzani A. Etiology of
Congenital Hypothyroidism. Thyroid Diseases in Childhood. Switzerland: Springer; 2015.h.27-31.

3. Seo MK, Yoon JS, So CH, Lee HS, Hwang JS. Intellectual development in preschool children with early treated congenital hypothyroidism. Ann Pediatr Endocrinol Metab 2017;22:102-7.

4. Frezzato RC, Santos DCC, Goto MMF, Ouro MPCd, Santos CTMd, Dutra V, dkk, penyunting. Fine motor skills and expressive language: a study with children with congenital hypotyreoidism. SciELO Brasil: CoDAS; 2017.

5. Morreale de Escobar G, Obregon MJ, Escobar del Rey F. Role of thyroid hormone during early brain development. Eur J endocrinol 2004;151 Suppl 3:U25-37.

6. Therrell BL, David-Padilla C. Screening of Newborns for Congenital Hypothyroidism: Guidance for Developing Programmes: IAEA; 2005.

7. Dalili S, Rezvani SM, Dalili H, Amiri ZM, Mohammadi $\mathrm{H}$, Kesh SA, dkk. Congenital hypothyroidism: etiology and growth-development outcome. Acta Med Iran 2014;52:752.

8. Desai MP. Congenital hypothyroidism: Screening dilemma. Indian J Endocrinol Metab 2012;16 Suppl 2:S153.

9. Campos MLP, Musso M, Keselman A, Gruneiro L, Bergadá I, Chiesa A. Cognitive profiles of patients with early detected and treated congenital hypothyroidism. Arch Argent Pediatr 2017;115:12-7.

10. Heidari Z, Feizi A, Hashemipour M, Kelishadi R, Amini M. Growth development in children with congenital hypothyroidism: the effect of screening and treatment variables-a comprehensive longitudinal study. Endocrine 2016;54:448-59.

11. Van der Sluijs Veer L, Kempers MJ, Wiedijk BM, Last BF, Grootenhuis MA, Vulsma T. Evaluation of cognitive and motor development in toddlers with congenital hypothyroidism diagnosed by neonatal screening. J Dev Behav Pediatr 2012;33:633-40.

12. Smith L. Updated AAP guidelines on newborn screening and therapy for congenital hypothyroidism. Amer acad Family Physicians; 2007.

13. Najmi SB, Hashemipour M, Maracy MR, Hovsepian S, Ghasemi M. Intelligence quotient in children with congenital hypothyroidism: The effect of diagnostic and treatment variables. J Res Med Sci $2013 ; 18: 395-9$.

14. Kooistra L, Laane C, Vulsma T, Schellekens JM, van der Meere JJ, Kalverboer AF. Motor and cognitive development in children with congenital hypothyroidism: a long-term evaluation of the effects of neonatal treatment. J Pediatr Pediatr Med 1994;124:903-9.

15. Buluş AD, Tiftik E. Evaluation of neurodevelopment of children with congenital hypothyroidism by the Denver Developmental 
Screening Test. J Pediatr Endocrinol Metab 2017;30:1061-6.

16. LaFranchi SH, Austin J. How should we be treating children with congenital hypothyroidism? J Pediatr Endocrinol Metab 2007;20:559-78.

17. Rustama D, Fadil MR, Harahap ER, Primadi A. Newborn screening in Indonesia. Southeast Asian J Trop Med Public Health 2004;34:76-9.

18. Frankenburg WK, Dodds J, Archer P, Shapiro H, Bresnick B. The Denver II: a major revision and restandardization of the Denver Developmental Screening Test. BMJ Paediatr Open 1992;89:91-7.

19. Accardo PJ, Capute AJ. The Capute Scales: Cognitive Adaptive Test/Clinical Linguistic \& Auditory Milestone Scale (CAT/ CLAMS). Illionis: Brookes Pub; 2005.

20. Büyükgebiz A. Newborn screening for congenital hypothyroidism. J Pediatr Endocrinol Metab 2006;19:1291-8.

21. Nakamizo M, Toyabe S-i, Asami T, Akazawa K. Mental development of infants with congenital hypothyroidism: a longitudinal study. Clin Pediatr 2007;46:53-8.

22. Scharf RJ, Stroustrup A, Conaway MR, DeBoer MD. Growth and development in children born very low birthweight. Arch Dis Child Fetal Neonatal Ed 2016;101:F433-8.
23. Bongers-Schokking JJ, Koot HM, Wiersma D, Verkerk PH, de Muinck Keizer-Schrama SM. Influence of timing and dose of thyroid hormone replacement on development in infants with congenital hypothyroidism. J Pediatr 2000;136:292-7.

24. Wirawan A, Sunartini S, Suryawan B, Soetjiningsih S. Tumbuh Kembang Anak Hipotiroid Kongenital yang Diterapi dini dengan Levo-tiroksin dan Dosis Awal Tinggi. Sari Pediatri 2016;15:69-74

25. 25. Claret C CJ, Goday A. Hypothyroidism and Down's syndrome. Rev Med Int Sindr Down 2013;17:18-24.

26. Pop VJ, Kuijpens JL, van Baar AL, Verkerk G, van Son MM, de Vijlder JJ, dkk. Low maternal free thyroxine concentrations during early pregnancy are associated with impaired psychomotor development in infancy. Clin Endocrinol 1999;50:149-55.

27. Haddow JE, Palomaki GE, Allan WC, Williams JR, Knight GJ, Gagnon J, dkk. Maternal thyroid deficiency during pregnancy and subsequent neuropsychological development of the child. BMJ Paediatr Open 1999;341:549-55.

28. Anastácio-Pessan FdL, CusinLamônica DA. Congenital hypothyroidism: influence for language and behavioral skills: study review. Revista CEFAC 2014;16:1990-6. 